\title{
Post Script Point
}

National Cancer Institute

\section{Source}

National Cancer Institute. Post Script Point. NCI Thesaurus. Code C71238.

A unit of leng th equal to $1 / 72$ of a British inch or 0.35277 millimeter. 